\title{
Microsatellite Instability and hMLH1 and hMSH2 Expression Analysis in Familial and Sporadic Colorectal Cancer
}

\author{
Sima Salahshor, Konrad Koelble, Carlos Rubio, and Annika Lindblom \\ Department of Molecular Medicine (SS, AL), and Department of Pathology and Cytology (CR) Karolinska Institute, \\ Stockholm, Sweden; and Department of Pathology (KK), Charite University Clinic, Berlin, Germany
}

\begin{abstract}
SUMMARY: Immunohistochemical expression analysis of mismatch repair gene products has been suggested for the prediction of hereditary nonpolyposis colorectal cancer (HNPCC) carrier status in cancer families and the selection of microsatellite instability (MSI)-positive tumors in sporadic colorectal cancer. In this study, we aimed to evaluate hMSH2 and hMLH1 immunohistochemistry in familial and sporadic colorectal cancer. We found that immunohistochemistry allowed us to identify patients with germline mutations in $h M S H 2$ and many cases with germline mutations in $h M L H 1$. However, some missense and truncating mutations may be missed. In addition, $h M L H 1$ promoter methylation, commonly occurring in familial and sporadic MSI-positive colorectal cancer, can complicate the interpretation of immunohistochemical expression analyses. Our results suggest that immunohistochemistry cannot replace testing for MSI to predict HNPCC carrier status or identify MSI-positive sporadic colorectal cancer. (Lab Invest 2001, 81:535-541).
\end{abstract}

$C$ olorectal cancer poses a major public health problem in most Western countries. At least $10 \%$ of the occurrences have been estimated to be attributable to a primary genetic factor (Lynch and de la Chapelle, 1999). Hereditary nonpolyposis colorectal cancer (HNPCC) is the most common syndrome with an increased risk for colorectal cancer. HNPCC families segregate germline mutations in one of the DNA mismatch repair (MMR) genes ( $h M L H 1, h M S H 2$, hPMS2, and hMSH6) (Kolodner, 1996). Microsatellite instability (MSI) is a characteristic molecular finding in most cases of HNPCC (Aaltonen et al, 1993; Tannergård et al, 1997), and 13\% of all cases of sporadic colorectal cancer (lonov et al, 1993; Thibodeau et al, 1993). MSI evolves through mutations or epigenetic alterations of genes involved in DNA mismatch repair. In HNPCC, inactivating mutations of MMR-genes cases have been shown to lead to MMR-deficiency and to MSI (Parsons et al, 1993). In MSI-positive sporadic tumors and also in MSI-positive HNPCC tumors, silencing of $h M L H 1$ involving promotor methylation has been associated with MMR-deficiency (Kane et al, 1997; Thibodeau et al, 1998; Kuismanen et al, 1999).

Identifying a gene mutation carrier conventionally requires extensive testing of mismatch repair genes known to be responsible for HNPCC. Efforts have been directed toward assessing the best strategy for selecting individuals for mutation screening. The de-

Received December 7, 2000.

Address reprint requests to: Dr. Annika Lindblom, Department of Molecular Medicine, Karolinska Institute, L8:02, S-17176 Stockholm, Sweden. E-mail:annika.lindblom@cmm.ki.se termination of tumoral microsatellites status or MSItesting has been suggested as the best method for selecting patients from colorectal cancer families for germline mutation analysis (Lamberti et al, 1999; Liu et al, 2000). Immunohistochemistry of MMR-genes has been used to identify tumors with a loss of protein expression (Kane et al, 1997; Deng et al, 1999). Because MSI is the functional consequence of the inactivation of the MMR gene(s), immunohistochemistry has been suggested as an alternative to MSItesting in selecting individuals for mutation screening (Marcus et al, 1999). The aim of the first part of this study was to determine whether immunohistochemistry could be used as an alternative to MSI-testing to predict a mutation carrier with a known germline mutation in $h M L H 1$ or $h M S H 2$. To this end we used tumors from patients with germline mutations in the $h M L H 1$ and $h M S H 2$ genes. The degree of $h M L H 1$ promoter methylation in HNPCC tumors and its relation to MSI status and MMR protein expression was also assessed.

It has been suggested that MSI-positive tumors and MSI-negative tumors might evolve through different mechanisms and sometimes even involve different pathways (Breivik and Gaudernack, 1999; Konishi et al, 1996; Olschwang et al, 1997; Salahshor et al, 1999b). Sporadic MSI-positive tumors show clinical differences compared with MSI-negative tumors. Like HNPCC tumors, they seem to have a better prognosis (Gryfe et al, 2000; Lothe et al, 1993; Salahshor et al, 1999a; Sankila et al, 1996). Sporadic MSI-positive tumors are almost exclusively localized to the right colon, and in one study it was found that right-sided tumors and tumors with MSI had a better response to 
adjuvant chemotherapy (Elsaleh et al, 2000). Thus, it could be clinically important to assess MSI status in sporadic tumors. Immunohistochemistry has been suggested to be a practical tool for identifying mismatch repair deficient tumors (Marcus et al, 1999). In the second part of this study, we evaluated the immunohistochemistry in identifying MSI-positive tumors among sporadic colorectal cancers. To this end, we studied sporadic colorectal tumors previously identified to be MSI-positive with immunohistochemistry for hMLH1 and hMSH2 protein expression (Salahshor et al, 1999a). We also tested hMLH1-promoter methylation in these tumors, which has been suggested to be an alternate mechanism of silencing of $h M L H 1$.

\section{Results}

\section{HNPCC Tumors with Germline hMLH1 Mutations}

Twenty-two tumors from patients with known germline mutations in the $h M L H 1$, including 8 cases with a truncating mutation and 15 cases with missense mutations, were investigated in this study (Table 1). Twenty of those 22 tumors were tested for protein expression, and all tumors expressed hMSH2. Fourteen of the 22 lacked hMLH1 expression. Six of those 14 had a truncating mutation, whereas the other 8 had missense mutations. All 14 tumors without hMLH1 staining were MSI-positive. However, both tumors with truncating and missense mutations also showed methylation of the promotor. One tumor (CT103) with a missense mutation in exon 10 was MSI-positive and expressed the protein. Because this mutation occurred together with a clearly pathogenic hMSH2 mutation, the pathogenic nature of this particular mutation is unknown. Three tumors (CT107, CT102, CT109) were microsatellite stable (MSS). These tumors had missense mutations within $h M L H 1$ exon 16, previously found to be associated with MSI-negative colorectal cancer (Liu et al, 1999). All three of these tumors expressed the hMLH1 protein (Table 1). In

Table 1. Genetic, Epigenetic, and Protein Expression Alteration of HNPCC Cases

\begin{tabular}{|c|c|c|c|c|c|c|c|c|}
\hline \multicolumn{3}{|c|}{ Kindreds } & \multirow[b]{2}{*}{ MSI } & \multicolumn{3}{|c|}{ hMLH1 } & \multicolumn{2}{|l|}{ hMSH2 } \\
\hline Family & Tumor & Lesion & & Mutation & $\mathrm{IHC}$ & Methyl & Mutation & $\mathrm{IHC}$ \\
\hline 1 & M104 & CRC & + & hMLH1del & - & $\mathrm{N}$ & & + \\
\hline 1 & CT64 & OVC & + & hMLH1del & - & $M$ & & + \\
\hline 1 & CT18 & CRC & + & hMLH1del & - & 0 & & + \\
\hline 1 & CT1 & CRC & + & hMLH1del & - & M & & + \\
\hline 34 & СT61 & CRC & + & Ex4-11del & - & 0 & & + \\
\hline 102 & CT212 & CRC & + & Ex6del & - & 0 & & + \\
\hline 7 & CT28 & CRC & + & Ex16del & + & 0 & & + \\
\hline 7 & M115 & CRC & + & Ex16del & + & $\mathrm{N}$ & & + \\
\hline 2 & CT45 & $A D$ & + & Ser44Phe(Ex2) & 0 & M & & 0 \\
\hline 2 & CT44 & CRC & + & Ser44Phe(Ex2) & - & 0 & & + \\
\hline 2 & CT4 & TVA & + & Ser44Phe(Ex2) & 0 & $\mathrm{M}$ & & 0 \\
\hline 2 & CT7 & EC & + & Ser44Phe(Ex2) & 0 & 0 & & + \\
\hline 2 & CT2 & CRC & + & Ser44Phe(Ex2) & - & M & & + \\
\hline 15 & СТ39 & CRC & + & Ser44Phe(Ex2) & - & $\mathrm{N}$ & & + \\
\hline 15 & CT41 & CRC & + & Ser44Phe(Ex2) & - & 0 & & + \\
\hline 18 & $A C$ & CRC & + & lle68Asn(Ex.2) & - & 0 & & + \\
\hline 3 & СТ30 & CRC & + & Met35Arg(Ex.1) & - & 0 & & + \\
\hline 3 & СТ29 & CRC & + & Met35Arg(Ex.1) & - & $\mathrm{N}$ & & + \\
\hline 3 & СТ31 & EC & + & Met35Arg(Ex.1) & - & 0 & & + \\
\hline $5 X$ & CT107 & CRC & - & Lys618Ala(Ex16) & + & 0 & & + \\
\hline 21 & CT102 & CRC & - & Glu578Gly(Ex16) & + & N & & + \\
\hline 21 & CT109 & CRC & - & Glu578Gly (Ex16) & + & 0 & & + \\
\hline$\ldots$ & $\ldots$ & $\ldots$ & $\cdots$ & $\ldots$ & & & & \\
\hline 80 & CT103 & CRC & + & Glu268Gly (Ex10) & + & 0 & $C A$ at 518 del (Ex10) & - \\
\hline 80 & CT105 & CRC & + & & + & 0 & CA at 518 del (Ex10) & - \\
\hline 80 & CT104 & UC & + & & + & 0 & CA at 518 del (Ex10) & - \\
\hline 5 & СT50 & CRC & + & & + & 0 & Del G at 67 (Ex.1) & - \\
\hline 5 & СТ83 & OVC & + & & + & 0 & Del G at 67 (Ex.1) & - \\
\hline 6 & СТ87 & CRC & + & & + & 0 & Gln298Stop & - \\
\hline 24 & СT96 & CRC & + & & + & 0 & Arg406Stop (Ex.7) & - \\
\hline 28 & CT14 & CRC & + & & + & $\mathrm{N}$ & Leu458Stop (Ex.8) & - \\
\hline 28 & $\mathrm{HH}$ & CRC & 0 & & 0 & 0 & Leu458Stop(Ex.8) & - \\
\hline
\end{tabular}

CRC, colorectal cancer; OVC, ovarian cancer; EC, endometrial cancer; TVA, tubulo-villous adenoma; UC, urothelial cancer; IHC, immunostaining; Methyl, hMLH1 promoter methylation test; 0 , no results available; N, normal methylation at hMLH1 promoter site; M, methylated; HNPCC, hereditary nonpolyposis colorectal cancer; MSI, microsatellite instability. 
total, 6 tumors (3 MSS and 3 MSI tumors) with germline hMLH1 mutations showed normal expression of the protein using immunohistochemistry. Two MSI-positive tumors had a truncating mutation in exon 16 (Fig. 1).

Only 10 of the 23 tumors with $h M L H 1$ mutations could be tested for methylation, and 5 of those (50\%) displayed hypermethylation of the $h M L H 1$ promoter. Three tumors showing promoter methylation (CT64, CT1, CT2), for which immunohistochemistry data was also available, did not express the hMLH1 protein. Thus, the lack of expression of protein and the resulting MSI could either be due to the mutation or to hypermethylation of the promoter. Of the five tumors without detectable methylation at the promoter, two expressed the protein, one with an exon 16 mutation (CT102, MSS) and one with a deletion in exon 16 (M115). Two tumors without methylation and without protein expression (M104, CT29) had a truncating mutation and a missense mutation, respectively. The MSI present in these 2 tumors (which could be studied immunohistochemically and lacked protein expres- sion) most likely were a result of the germline mutations detected.

\section{HNPCC Tumors with Germline hMSH2 Mutations}

Nine tumors from patients with truncating germline mutation in the $h M S H 2$ were studied (Table 1). In one case (CT103), an additional $h M L H 1$ exon 10 missense mutation of unknown significance was present. All eight tumors were tested for protein expression, and all tumors expressed hMLH1. No tumor with $h M S H 2$ germline mutation showed nuclear hMSH2 expression (Table 1). However, in two tumors with hMSH2 mutation, a distinct pattern of localization could be observed. In one case with a nonsense mutation at codon 458 (CT14) and another with a deletion at codon 513 (CT104), pronounced hMSH2 immunoreactivity in the cytoplasm could be detected. To explore the possibility of the existence of $h M S H 2$ isoforms preferentially localizing in the cytoplasm, we extracted protein from Epstein-Barr virus (EBV)transformed cell lines from the patients and performed
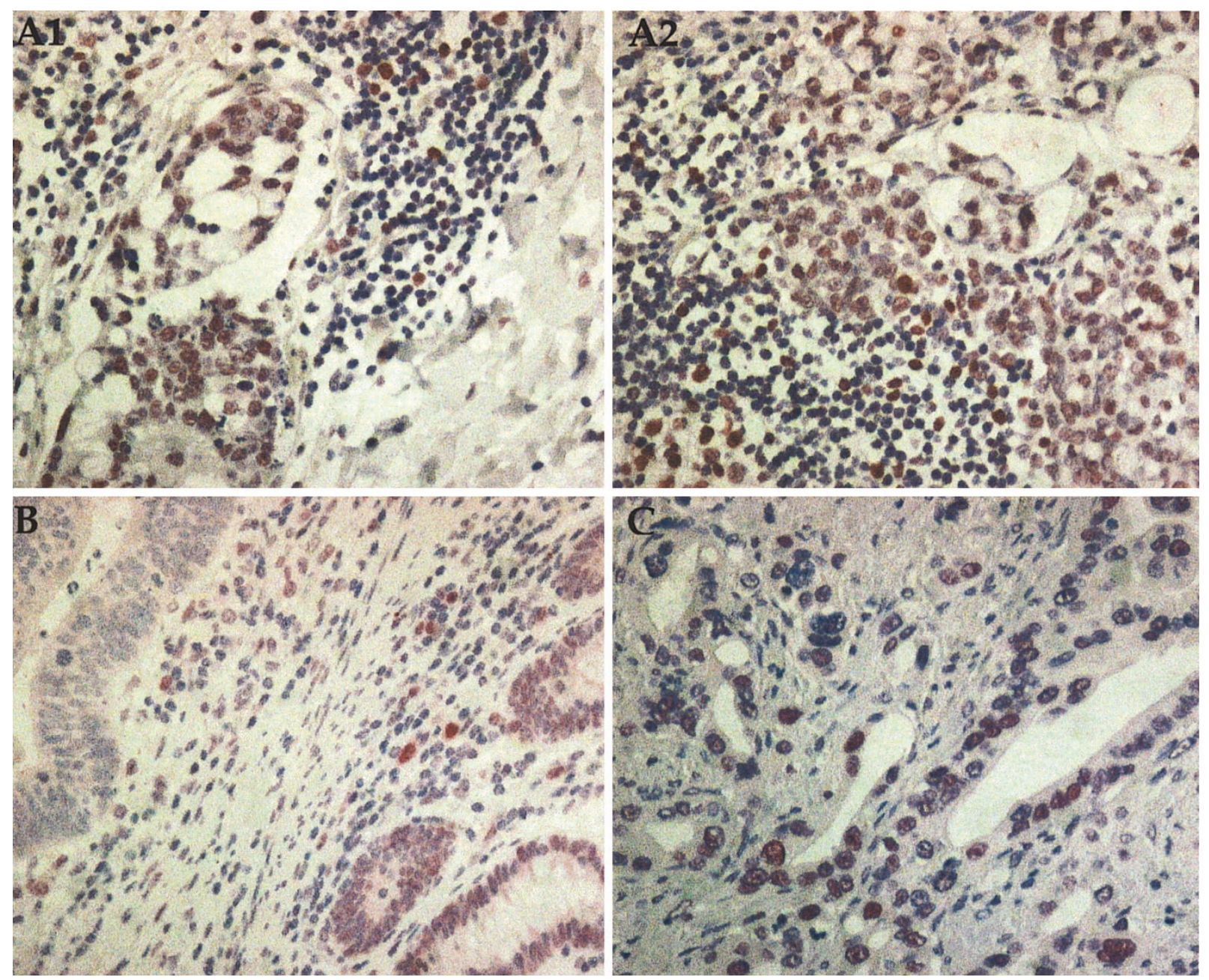

\section{Figure 1.}

Immunostaining for MLH1/MSH2 in colorectal tumors from HNPCC patients with known germline mutations (Table 1). A, Case M115, with exon 16 deletion in hMLH1 and positive hMLH1 (A1) and hMSH2 (A2) staining. B, Case CT44 with missense mutation in exon 2 of hMLH1 and negative hMLH1 staining. C, Case CT102 with missense mutation in exon 16 of $h M L H 1$ and positive hMLH1 expression. 
Western blot analyses. No aberrant protein could be detected in any of the cell lines with cytoplasmic expression (Fig. 2). However, this does not rule out the possibility that the aberrant compartmentalization of $\mathrm{hMSH} 2$ in these cases may be due to second somatic mutational hits.

\section{Sporadic MSI-Positive Tumors}

Immunohistochemical assays were performed on 19 MSI-positive sporadic colorectal tumors. All 19 tumors were hMSH2 positive using immunohistochemistry (Table 2). Fifteen of the 19 (79\%) were found to lack hMLH1 protein expression, whereas 4 tumors were positive (21\%). None of these tumors were screened for any of the mismatch repair genes. The promoter region of hMLH1 was hypermethylated in 7 of 15 $(47 \%)$ tumors without hMLH1 protein expression (Table 2).

\section{Discussion}

\section{Use of Immunohistochemistry in HNPCC Cases}

In this study the possibility of selecting individuals for mutation screening by immunohistochemistry was explored. The correlation between $h M L H 1$ germline mutation and lack of hMLH1 protein expression using immunohistochemistry was not complete because tumors of six patients with germline mutations did express the hMLH1 protein. Of these six tumors, three had of a type mutation previously suggested to be disease related, although their tumors were MSS (Liu et al, 1999). Two cases with normal hMLH1 expression were MSI-positive. These two tumors had the common exon 16 truncation mutation (Table 1, Family 7) suggesting that the specific antibody's epitope is located N-terminally the exon 16-encoded part of MLH1. The MSI in tumor CT103 likely relates to the hMSH2 mutation, segregating with disease in the family, and the consequence of the hMLH1 missense mutation is unclear. However, other missense mutations in exon 10 in $h M L H 1$ are known to be disease causing. Our data demonstrated that immunohistochemistry with the most widely used anti-MLH1 monoclonal antibody failed to detect the translational

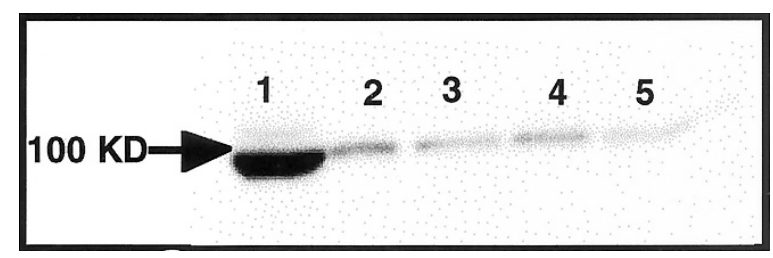

Figure 2.

Western blot analysis of protein extracted from Epstein-Barr virus (EBV)transformed cell lines from patients with germline mutation in the hMSH2 gene. (1) HCT-116 cell line has been used as a positive control. (2) A case from Family 28 with nonsense mutation. Immunohistochemical staining shows a negative nuclear staining with abnormal cytoplasmic staining. (3) Case from Family 24 with nonsense mutation and negative hMSH2 immunostaining. (4) Case from Family 7 with no mutation in the hMSH2 gene and positive hMSH2 on immunohistochemical staining (IHC). (5) Case from Family 6 with nonsense mutation in $h M S H 2$ and negative MSH2 immunostaining.
Table 2. MSI Status, hMLH1 and hMSH2 Staining, and hMLH1 Promoter Methylation Status in 19 Sporadic MSI Positive Colorectal Tumors

\begin{tabular}{|c|c|c|c|c|}
\hline \multirow[b]{2}{*}{ Tumor No. } & \multirow[b]{2}{*}{ MSI status } & \multicolumn{2}{|c|}{ hMLH1 } & \multirow{2}{*}{$\frac{\mathrm{hMSH} 2}{\mathrm{IHC}}$} \\
\hline & & $\mathrm{IHC}$ & Methyl & \\
\hline 73 & + & - & $M$ & + \\
\hline 89 & + & - & $M$ & + \\
\hline 99 & + & - & $M$ & + \\
\hline 153 & + & - & $M$ & + \\
\hline 177 & + & - & M & + \\
\hline 190 & + & - & $M$ & + \\
\hline 193 & + & - & M & + \\
\hline 10 & + & - & $\mathrm{N}$ & + \\
\hline 61 & + & - & $\mathrm{N}$ & + \\
\hline 68 & + & + & $\mathrm{N}$ & + \\
\hline 88 & + & - & $\mathrm{N}$ & + \\
\hline 108 & + & - & $\mathrm{N}$ & + \\
\hline 128 & + & + & $\mathrm{N}$ & + \\
\hline 134 & + & - & $\mathrm{N}$ & + \\
\hline 141 & + & - & $\mathrm{N}$ & + \\
\hline 151 & + & - & $\mathrm{N}$ & + \\
\hline 180 & + & - & $\mathrm{N}$ & + \\
\hline 182 & + & + & $\mathrm{N}$ & + \\
\hline 192 & + & + & $\mathrm{N}$ & + \\
\hline
\end{tabular}

IHC, immunohistochemistry; Methyl, hMLH1 promoter methylation status; $\mathrm{M}$, methylated; N, normal.

effects of some missense and even some truncating hMLH1 germline mutations. A similar lack of correlation between some germline mutations and protein expression was reported in another study (Ichikawa et al, 1999). Yet two other studies found a good correlation between germline mutations and lack of protein expression (Cunningham et al, 1998; Marcus et al, 1999). However, in the study by Cunningham et al, tumors also showed signs of promoter methylation that were not looked for in the study by Marcus et al. Thus, there is no consensus regarding the use of immunohistochemical expression analysis alone as a predictor of germline mutations in the $h M L H 1$ gene.

In contrast, all eight HNPCC cases with $h M S H 2$ germline mutation lacked protein expression of the corresponding gene as determined by immunohistochemistry. In all of these cases, the absence of hMSH2 expression could be associated with the truncating mutation, which is the most common type of pathogenic germline mutation in $h M S H 2$. These results indicate that immunohistochemistry could be more efficient in predicting potential carriers with hMSH2 mutations than those with hMLH1 mutations.

\section{Use of Immunohistochemistry in Sporadic Colorectal Cancer}

In 15 of 19 (79\%) MSI-positive sporadic colorectal cancer cases studied, no expression of $h M L H 1$ protein was detected. This is in agreement with a previous report (Dietmaier et al, 1997). The four tumors that did express the protein may have somatic mutations in any of the mismatch repair genes that were not 
detected by immunohistochemistry. In general, immunohistochemistry can be used clinically to identify MSI-positive tumors. However, a significant fraction of these will remain undetected. Clearly localizing the exact epitopes of the monoclonal antibodies used in this and other studies could provide a refined rationale for the use of immunohistological expression analysis in the diagnosis of sporadic as well as inherited mismatch repair-deficiency states.

\section{MLH1 Promoter Hypermethylation: Cause or Consequence}

Promoter hypermethylation of cytosine-phosphorothioateguanine (CpG) islands of $h M L H 1$ promoter is not restricted to colorectal cancer (Costello et al, 2000). It has previously been shown that methylation begins in the normal colon mucosa as an age-related event and progresses to hypermethylation in cancer (Ahuja et al, 1998; Toyota et al, 1999). These studies support the idea that hypermethylation is not always restricted to tumors. Whereas in HNPCC, tumoral MSI is thought to be due predominantly to inactivating mutations in the $h M L H 1$ or hMSH2 genes, sporadic MSI-positive colorectal cancers seem more often associated with methylation of the hMLH1 promoter. Hypermethylation of hMLH1 promoter region have been detected in more than $50 \%$ of sporadic colorectal tumors lacking hMLH1 protein expression (Cunningham et al, 1998; Wheeler et al, 2000). The finding of frequent methylation of $h M L H 1$ promoter also in the familial cases suggests that the correlation of MSI and mismatch repair genes deficiency may be even more complex. The methylation of some of the HNPCC tumors may simply reflect the global redistribution of 5-methylcytosine during cancer development (Baylin et al, 1998; Schmutte and Jones, 1998) with little functional significance. It is also possible that DNA methylation of promoter-associated $\mathrm{CpG}$ islands may represent an alternative mechanism to deletional processes as indicated by loss of heterozygosity. We even detected $h M L H 1$ promoter hypermethylation in pre-malignant adenomatous polyps in two HNPCC cases (Table 1, CT4 and CT45) which supports the idea that methylation is an early event also in HNPCC carcinogenesis.

In summary, in this study we found that immunohistochemistry identifies most of the patients with germline mutations in $h M S H 2$ and many cases with germline mutations in $h M L H 1$. However, missense mutations and even truncating mutations of $h M L H 1$ may be missed. Moreover, methylation of the $h M L H 1$ promoter is common in familial as well as in sporadic MSI colorectal cancer, which suggests that the lack of immunohistochemical $h M L H 1$ reactivity could lead to the erroneous inclusion of a patient in germ line sequencing efforts. Because the majority of sporadic MSI-positive tumors show hypermethylation of hMLH1 promoter and lack protein expression, immunohistochemistry provides a rapid screening tool for the identification of sporadic tumors with MSI. Nevertheless, even in this context, standard electrophoretic testing for MSI will provide a higher sensitivity. Although immunohistochemistry is unquestionably valu- able, especially in the investigation of $h M S H 2$-related HNPCC and hMLH1-related sporadic colorectal cancers, it is somewhat unreliable as a method that might replace the PCR-based tests for microsatellite instability.

\section{Materials and Methods}

\section{Tumors}

Thirty-one tumors from 15 HNPCC families, with known germline mutations in $h M L H 1$ or $h M S H 2$, were investigated (Liu et al, 2000; Wahlberg et al, 1999). In addition, $19 \mathrm{MSI}$-positive sporadic colorectal cancer cases selected from 191 consecutively collected tumors also were examined. In previous studies, the MSI status of these tumors was established using monoand dinucleotide repeats markers (Liu et al, 2000; Salahshor et al, 1999a). Criteria used for microsatellite instability or high frequency $\mathrm{MSI}(\mathrm{MSI}-\mathrm{H})$ followed published guidelines (Boland et al, 1998; Perucho, 1999).

\section{DNA Methylation Analysis}

Genomic DNA samples were analyzed for the presence of hypermethylation at potential $h M L H 1$ promoter sites (from codon -670 to -67) using PCRbased Hpall restriction enzyme assay as detailed previously (Kane et al, 1997). The DNA was digested with Hpall or Mspl enzymes. Digested and undigested DNA was amplified using a single primer pair (MLH127494: CGCTGCTAGTATTCGTGC and MLH1-25266: TCAGTGCCTCGTGCTCAC), electrophoretically separated in $1 \%$ agarose gels, stained with ethidium bromide, and visualized under UV illumination (Kane et al, 1997). Unmethylated and methylated positive controls were included in all reactions (Fig. 3).

\section{Immunohistochemistry}

For the immunohistochemical expression analysis of the mismatch repair proteins hMSH2 and hMLH1, all available tumors were stained using the murine immunoglobulin G ( $\mathrm{ggG}$ ) monoclonal antibodies clone FE11 (Calbiochem, San Diego, California) and clone G168-15 (BD PharMingen, San Diego, California), respectively. Three-micron sections were mounted on SuperFrost Plus glass slides, baked overnight at $45^{\circ} \mathrm{C}$, deparaffinized in xylene, rehydrated in descending ethanol, and washed in water. For antigen

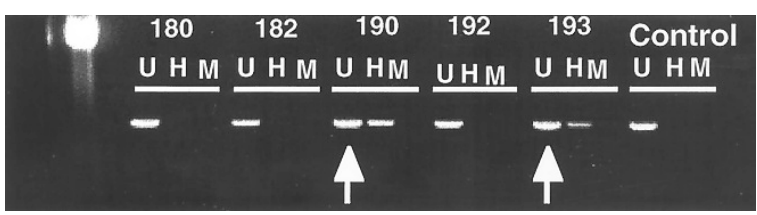

Figure 3.

Methylation analysis of cytosine-phosphorothioate-guanine $(\mathrm{CpG})$ islands in hMLH1 promoter in colorectal tumors. U, undigested DNA samples; H, DNA digested with Hpall enzyme; M, DNA digested with Mspl enzyme. Samples 190 and 193, indicated with arrows, are methylated. 
retrieval, the slides were pressure-cooked in citric acid buffer ( $\mathrm{pH}$ 6.5) for 5 minutes. Sections were incubated in 1:50 dilutions of the respective antibodies for 30 minutes at room temperature. Antigen-antibody complexes were visualized using standard alkaline phosphatase-antialkaline phosphatase techniques with Fast Red TR/Naphthol AS-MX (Sigma Aldrich Co., St. Louis, Missouri) as the chromogenic substrate. Slides were counterstained with methylene blue and coverslipped. Only nuclear immunolocalization of the MMR proteins was considered in the scoring. Cancer cells without nuclear signals were only scored as negative if neighboring lymphocytes or normal epithelial cells showed nuclear staining.

\section{Western Blotting}

Approximately $10^{6}$ EBV-transformed cells were lysed in lysis buffer (20 mm HEPES, pH 7.6; 20\% glycerol; 10 mм NaCl; 1.5 mм MgCl; 0.2 mM EDTA; 0.1\% Triton $\mathrm{X}-100 ; 1 \mathrm{~mm}$ dithiothreitol) and $1 \mathrm{~mm}$ phenylmethylsulphonyl fluoride was added. Fifty micrograms of proteins were subjected to SDS-PAGE as described (Sambrook and Gething, 1989). Proteins were transferred to polyvinylidene difluoride (PVDF) membranes and stained against a 1\% Ponceau S. solution (SigmaAldrich, Stockholm, Sweden) to check the loadings and incubated with the primary and secondary antibodies overnight at $4^{\circ} \mathrm{C}$ in a solution containing PBS plus $0.1 \%$ Tween 20 and $4 \%$ milk. After washing with PBS plus $0.1 \%$ Tween 20 , filters were probed with the same mouse monoclonal antibodies used for immunohistochemical staining (IHC), namely clone G168728 (PharMingen) at 1:200 and clone FE11 (Calbiochem) at 1:200. Filters were incubated with enhanced chemiluminescent (ECL) substrate (Amersham, Les Ulis, France) and exposed to Hyperfilm (Amersham). Immune complexes were visualized with enhanced chemiluminescence by an image analyzer (Image Reader LAS-1000; Fuji, Tokyo, Japan).

\section{References}

Aaltonen L, Peltomaki P, Leach F, Sistonen P, Pylkkanen L, Mecklin J, Jarvinen H, Powell S, Jen J, and Hamilton SR (1993). Clues to the pathogenesis of familial colorectal cancer. Science 260:812-816.

Ahuja N, Li Q, Mohan AL, Baylin SB, and Issa JP (1998). Aging and DNA methylation in colorectal mucosa and cancer. Cancer Res 58:5489-5494.

Baylin SB, Herman JG, Graff JR, Vertino PM, and Issa JP (1998). Alterations in DNA methylation: A fundamental aspect of neoplasia. Adv Cancer Res 72:141-196.

Boland CR, Thibodeau SN, Hamilton SR, Sidransky D, Eshleman JR, Burt RW, Meltzer SJ, Rodriguez-Bigas MA, Fodde R, Ranzani GN, and Srivastava S (1998). A National Cancer Institute workshop on microsatellite instability for cancer detection and familial predisposition: Development of international criteria for the determination of microsatellite instability in colorectal cancer. Cancer Res 58:5248-5257.
Breivik J and Gaudernack G (1999). Genomic instability, DNA methylation, and natural selection in colorectal carcinogenesis. Semin Cancer Biol 9:245-254.

Costello JF, Fruhwald MC, Smiraglia DJ, Rush LJ, Robertson GP, Gao X, Wright FA, Feramisco JD, Peltomaki P, Lang JC, Schuller DE, Yu L, Bloomfield CD, Caligiuri MA, Yates A, Nishikawa R, Su Huang $\mathrm{H}$, Petrelli NJ, Zhang X, O'Dorisio MS, Held WA, Cavenee WK, and Plass C (2000). Aberrant $\mathrm{CpG}$-island methylation has non-random and tumour-typespecific patterns. Nat Genet 24:132-138.

Cunningham JM, Christensen ER, Tester DJ, Kim CY, Roche PC, Burgart LJ, and Thibodeau SN (1998). Hypermethylation of the hMLH1 promoter in colon cancer with microsatellite instability. Cancer Res 58:3455-3460.

Deng G, Chen A, Hong J, Chae HS, and Kim YS (1999). Methylation of $\mathrm{CpG}$ in a small region of the $\mathrm{hMLH} 1$ promoter invariably correlates with the absence of gene expression. Cancer Res 59:2029-2033.

Dietmaier W, Wallinger S, Bocker T, Kullmann F, Fishel R, and Ruschoff J (1997). Diagnostic microsatellite instability: Definition and correlation with mismatch repair protein expression. Cancer Res 57:4749-4756.

Elsaleh H, Joseph D, Grieu F, Zeps N, Spry N, and lacopetta B (2000). Association of tumour site and sex with survival benefit from adjuvant chemotherapy in colorectal cancer. Lancet 355:1745-1750.

Gryfe R, Kim H, Hsieh ET, Aronson MD, Holowaty EJ, Bull SB, Redston M, and Gallinger S (2000). Tumor microsatellite instability and clinical outcome in young patients with colorectal cancer. N Engl J Med 342:69-77.

Ichikawa $\mathrm{Y}$, Lemon SJ, Wang S, Franklin B, Watson $\mathrm{P}$, Knezetic JA, Bewtra C, and Lynch HT (1999). Microsatellite instability and expression of MLH1 and $\mathrm{MSH} 2$ in normal and malignant endometrial and ovarian epithelium in hereditary nonpolyposis colorectal cancer family members. Cancer Genet Cytogenet 112:2-8.

Ionov Y, Peinado MA, Malkhosyan S, Shibata D, and Perucho M (1993). Ubiquitous somatic mutations in simple repeated sequences reveal a new mechanism for colonic carcinogenesis. Nature 363:558-561.

Kane MF, Loda M, Gaida GM, Lipman J, Mishra R, Goldman $H$, Jessup JM, and Kolodner R (1997). Methylation of the hMLH1 promoter correlates with lack of expression of hMLH1 in sporadic colon tumors and mismatch repairdefective human tumor cell lines. Cancer Res 57:808-811.

Kolodner R (1996). Biochemistry and genetics of eukaryotic mismatch repair. Genes Dev 10:1433-1442.

Konishi M, Kikuchi-Yanoshita R, Tanaka K, Muraoka M, Onda A, Okumura Y, Kishi N, Iwama T, Mori T, Koike M, Ushio K, Chiba M, Nomizu S, Konishi F, Utsunomiya J, and Miyaki M (1996). Molecular nature of colon tumors in hereditary nonpolyposis colon cancer, familial polyposis, and sporadic colon cancer. Gastroenterology 111:307-317.

Kuismanen SA, Holmberg MT, Salovaara R, Schweizer P, Aaltonen LA, de La Chapelle A, Nystrom-Lahti M, and Peltomaki P (1999). Epigenetic phenotypes distinguish microsatellite-stable and -unstable colorectal cancers. Proc Natl Acad Sci USA 96:12661-12666. 
Lamberti C, Kruse R, Ruelfs C, Caspari R, Wang Y, Jungck $M$, Mathiak M, Malayeri HR, Friedl W, Sauerbruch T, and Propping $P$ (1999). Microsatellite instability-A useful diagnostic tool to select patients at high risk for hereditary nonpolyposis colorectal cancer: A study in different groups of patients with colorectal cancer. Gut 44:839-843.

Liu T, Tannergård $P$, Hackman $P$, Rubio $C$, Kressner U, Lindmark G, Hellgren D, Lambert B, and Lindblom A (1999). Missense mutations in hMLH1 associated with colorectal cancer. Human Genet 105:437-441.

Liu T, Wahlberg S, Burek E, Lindblom P, Rubio C, and Lindblom A (2000). Microsatellite instability as a predictor of a mutation in a DNA mismatch repair gene in familial colorectal cancer. Genes Chromosomes Cancer 27:17-25.

Lothe RA, Peltomäki P, Meling GI, Aaltonen LA, NystromLahti M, Pylkkanen L, Heimdal K, Andersen TI, Möller P, and Rognum TO (1993) Genomic instability in colorectal cancer: relationship to clinicopathological variables and family history. Cancer Res 53:5849-5852.

Lynch HT and de la Chapelle A (1999) Genetic susceptibility to non-polyposis colorectal cancer. J Med Genet 36:801818.

Marcus VA, Madlensky L, Gryfe R, Kim H, So K, Millar A, Temple LK, Hsieh E, Hiruki T, Narod S, Bapat BV, Gallinger S, and Redston M (1999). Immunohistochemistry for hMLH1 and hMSH2: A practical test for DNA mismatch repairdeficient tumors. Am J Surg Pathol 23:1248-1255.

Olschwang S, Hamelin R, Laurent-Puig P, Thuille B, De Rycke Y, Li YJ, Muzeau F, Girodet J, Salmon RJ, and Thomas $G$ (1997). Alternative genetic pathways in colorectal carcinogenesis. Proc Natl Acad Sci USA 94:12122-12127.

Parsons R, Li GM, Longley MJ, Fang WH, Papadopoulos N, Jen J, de la Chapelle A, Kinzler KW, Vogelstein B, and Modrich P (1993). Hypermutability and mismatch repair deficiency in RER+ tumor cells. Cell 75:1227-1236.

Perucho M (1999). Correspondence re: C. R. Boland et al, A National Cancer Institute workshop on microsatellite instability for cancer detection and familial predisposition: Development of international criteria for the determination of microsatellite instability in colorectal cancer (Cancer Res 58:52485257, 1998). Cancer Res 59:249-256.
Salahshor S, Kressner U, Fischer H, Lindmark G, Glimelius B, Påhlman L, and Lindblom A (1999a). Microsatellite instability in sporadic colorectal cancer is not an independent prognostic factor. Br J Cancer 81:190-193.

Salahshor S, Kressner U, Påhlman L, Glimelius B, Lindmark G, and Lindblom A (1999b). Colorectal cancer with and without microsatellite instability involves different genes. Genes Chromosomes Cancer 26:247-252.

Sambrook J and Gething MJ (1989). Protein structure. Chaperones, paperones. Nature 342:224-225.

Sankila R, Aaltonen LA, Järvinen HJ, and Mecklin JP (1996). Better survival rates in patients with MLH1-associated hereditary colorectal cancer. Gastroenterology 110:682-687.

Schmutte C and Jones PA (1998). Involvement of DNA methylation in human carcinogenesis. J Biol Chem 379:377388.

Tannergård P, Liu T, Weger A, Nordenskjöld M, and Lindblom A (1997). Tumorigenesis in colorectal tumors from patients with hereditary non-polyposis colorectal cancer. Hum Genet 101:51-55.

Thibodeau S, Bren G, and Schaid D (1993). Microsatellite instability in cancer of the proximal colon. Science 260:816819 .

Thibodeau SN, French AJ, Cunningham JM, Tester D, Burgart LJ, Roche PC, McDonnell SK, Schaid DJ, Vockley CW, Michels VV, Farr GH Jr, and O'Connell MJ (1998). Microsatellite instability in colorectal cancer: Different mutator phenotypes and the principal involvement of hMLH1. Cancer Res 58:1713-1718.

Toyota M, Ahuja N, Ohe-Toyota M, Herman JG, Baylin SB, and Issa JP (1999). CpG island methylator phenotype in colorectal cancer. Proc Natl Acad Sci USA 96:8681-8686.

Wahlberg S, Liu T, Lindblom P, and Lindblom A (1999). Various mutation screening techniques in the DNA mismatch repair genes hMSH2 and hMLH1. Genet Test 3:259-264.

Wheeler JM, Loukola A, Aaltonen LA, Mortensen NJ, and Bodmer WF (2000). The role of hypermethylation of the hMLH1 promoter region in HNPCC versus MSI+ sporadic colorectal cancers. J Med Genet 37:588-592. 